\title{
PELATIHAN PEMBUATAN PARFUM LAUNDRY AROMA TERAPI BUNGA LAVENDER DI GAMPONG SUNGAI PAUH PUSAKA
}

\section{A TRAINING FOR MAKING LAUNDRY PERFUMES LAVENDER FLOWER THERAPY IN GAMPONG SUNGAI PAUH PUSAKA}

\author{
Elfrida $^{1)}$, Rizky Nafaida ${ }^{2)}$, Nursamsu $^{3)}$ \\ ${ }^{1,2}$ Pendidikan Biologi, Universitas Samudra \\ ${ }^{3}$ Pendidikan Fisika, Universitas Samudra \\ ${ }^{1}$ Email: samsu_bio@unsam.ac.id
}

\begin{abstract}
Abstrak: Gampong Sungai Pauh Pusaka Kecamatan Langsa Barat Kota Langsa merupkan lokasi sasaran kegiatan pengabdian kepada masyarakat pada tahun 2021 yang dilaksanakan oleh tim pengabdian. Bunga lavender sangat bermanfaat dijadikan parfum pewangi pakaian. Sebab itulah tim pengabdian termotivasi untuk membuat parfum laundry kepada mitra sebagai peserta pelatih. Tujuan dari kegiatan ini berupa pelatihan bagi Ibu PKK yang akan dilatih untuk membuat produk parfum laundry aroma bunga lavender. Metode kegiatan ini berupa metode pelatihan yang terdiri beberapa tahapan yaitu survey, pelatihan serta monitoring dan evaluasi. Hasil dari kegiatan ini berdampak positif bagi Ibu PKK yang akan dijadikan produk unggulan daerah dan usaha pendapatan penghasilan gampong.
\end{abstract}

Kata Kunci: Parfum, Laundry, Bunga lavender

Abstract: Gampong Sungai Pauh Pusaka Kecamtan Langsa Barat Kota Langsa is the target location for community service activities in 2021 which will be carried out by the service team. Lavender flowers are very useful as a perfume for clothes. That's why the service team is motivated to make laundry perfumes for partners as trainers. The purpose of this activity is in the form of training for PKK mothers who will be trained to make lavender perfume laundry products. The method of this activity is a training method consisting of several stages, namely survey, training and monitoring and evaluation. The results of this activity have a positive impact on Ms. PKK who will be used as regional superior products and gampong income income businesses.

Keywords: Parfume, Laundry, Lavender flowers

\section{PENDAHULUAN}

\section{Analisis Situasi}

Daerah Kota Langsa khususnya Gampong Sungai Pauh Pusaka banyak sekali masyarakat yang menggunakan softener pelembut dan pewangi pakaian 
INTEGRITAS : Jurnal Pengabdian

Vol 5 No 2 Desember 2021

ISSN 2580- 7978 (cetak) ISSN 2615-0794 (online)

dengan harga yang mahal dipasaran sehingga membuat masyarakat merasa keberatan dalam harga dengan itu kami bermaksud membuat produk yang dapat dijangkau oleh berbagai kalangan masyarakat karena hargnya lebih terjangkau dibandingkan dengan harga di pasaran. sehingga kami membuat inovasi baru yaitu membuat parfum laundry Aroma terapi Anti Nyamuk (Aedes aegypti).

Aroma terapi adalah teknik pengobatan dengan aroma minyak esensial dari proses penyulingan berbagai bagian tanaman, bunga, maupun pohon yang masing-masing mengandung sifat terapi yang berbeda (Ohayon, 2015). Minyak esensial dari bunga lavender (Lavandula angustifolia) memberikan efek sedativ karena mengandung bahan aktif utama yaitu linalool $\left(\mathrm{C}_{10} \mathrm{H}_{18} \mathrm{O}\right)$ (Ohayon, 2015). Menurut Aromaterapi lavender adalah terapi yang menggunakan minyak essensial yang dinilai dapat membantu mengurangi bahkan mengatasi gangguan psikologis dan gangguan rasa nyaman seperti cemas, stress, depresi, dan sebagainya (Afrianti, 2015).

Berdasarkan penelitian, dalam 100 gram bunga lavender Lavandula angustifolia) tersusun atas beberapa kandungan, seperti minyak esensial (1-3\%), alpha-pinene $(0,22 \%)$, camphene $(0,06 \%)$, beta-myrcene $(5,33 \%)$, cymene $(0,3 \%)$, limonene $(1,06 \%)$, cineol $(0,51 \%)$, linalool $(26,12 \%)$, borneol $(1,21 \%)$, terpinine-4-ol (4,64\%), linalyl acetate $(26,32 \%)$, geranyl acetate $(2,14 \%)$, dan caryophyllene $(7,55 \%)$. Sehingga dapat disimpulkan bahwa kandungan utama dari bunga lavender adalah linalyl asetat dan linalool7 $\left(\mathrm{C}_{10} \mathrm{H}_{18} \mathrm{O}\right)$. Tetapi, linalyl asetat sebagai kandungan utama dari bunga lavender tidak tidak memiliki efek sedatif yang signifikan terhadap penurunan risiko insomnia (Contrad, 2012).

Bunga lavender dapat dijadikan pewangi pakaian, disebabkan bunga lavender menghasilkan wangi yang harum dan bermanfaat. Dengan demikian pewangi pakaian sering digunakan bagi ibu-ibu rumah tangga untuk kebutuhan rumah tangga. Pewangi pakaian merupakan salah satu bahan berupa cairan yang terjadi dalam proses tahapan awal dan akhir membuat pakaian yang dicuci menjadi lembut dan wangi (Laksono, 2018). Menurut pendapat Handoko (2009) menyatakan bahwa softener dengan $\mathrm{pH}$ netral dapat membuat kondisi pencucian mempermudah mencakup terhadap permukaan kain. Pewangi ini sangat lembut 
serta dapat meninggalkan aroma yang tahan lama pada serat kain.

Bahan utama pelembut dan pewangi pakaian adalah surfaktan yang sering digunakan oleh industri (Scheibel, 2004). Parfum laundry yang biasanya berada di pasaran menawarkan berbagai macam Jenis Parfum yang memiliki harga sangat mahal sehingga sulit untuk dijangkau kalangan masyarakat dengan ini kami membuat parfum Aroma terapi Anti Nyamuk (Aedes aegypti) yang memiliki unggulan yang menjajikan yang sangat potensial dan memiliki prospek pengembangan yang positif. Sejauh ini belum ada produsen yang memproduksi produk tersebut.

Melihat beberapa produk parfum laundry yang telah beredar dan cakupan pemasaran yang luas, menjadikan produk parfum laundry sangat diminati oleh masyarakat, tetapi parfum laundry di pasaran harganya cukup mahal sehingga membuat konsumen kurang minat untuk membelinya dan pada saat ini, dunia sedang menghadapi pademi Covid-19 yang berdampak negatif bagi perekonomian masyarakat, sehingga rendahnya peminat masyarakat untuk membeli parfum laundry di pasaran.

Dengan melihat fenomena yang terjadi kami berencana berupaya mencari alternatif yaitu dengan membuat pewangi dan pelembut pakaian sekali bilas dengan harga terjangkau dan juga berkualitas adalah inovasi kami dalam pembuatan parfum laundry yang berbeda dari produk-produk pelembut dan pewangi pakaian lainnya. Selosoft memiliki keunggulan dengan harga terjangkau yang dapat di jangkau oleh seluruh kalangan masyarakat. Keunggulan utama dari produk Selosoft adalah menggunakan Aroma terapi Anti- Nyamuk (Aedes aegypti) yang tidak menimbulkan bau apek di pakaian, tidak menimbulkan bercak dipakaian, Aromanya menempel hingga berhari- hari walau pun sudah digunakan sehingga Nyamuk Aedes aegypti yang menyukai pakaian yang digantung yang meninggalkan bau dapat menghindari karena pakaian memiliki aroma terapi antinyamuk (Aedes aegypti) dengan begitu dapat mengurangi sarang nyamuk pada pakaian dilemari yang dapat menularkan virus dengue sebagai penyebab demam berdarah (DBD). 
INTEGRITAS : Jurnal Pengabdian

Vol 5 No 2 Desember 2021

ISSN 2580 - 7978 (cetak) ISSN 2615 - 0794 (online)

Berdasarkan hal tersebut produk ini merupakan Sebagai Inovasi Parfum Laundry Aroma Terapi Anti Nyamuk (Aedes aegypti) yang sangat membantu pakaian dalam sekali bilas aroma dan pelembut langsung bekerja. Oleh karena itu produk parfum laundry ini perlu dikembangkan dan dipasarkan untuk memenuhi kebutuhan masyarakat.

\section{Permasalahan Mitra}

Berdasarkan analisis situasi yang telah dipaparkan, permasalahan yang dihadapi mitra adalah sebagai berikut: (1) Banyaknya masyarakat terutama ibu rumah tangga tidak mengetahui manfaat Aroma terapi lavender sebagai AntiNyamuk (Aedes aegypti) untuk pembuatan pelembut dan pewangi pakaian; (2) Kurangnya ketrampilan mitra untuk berkreasi dan berinovasi membuat produk; (3) Minimnya keterampilan berwirausaha bagi ibu rumah tangga dalam membantu perekonomian keluarga.

\section{Justifikasi Solusi Atas Permasalahan Mitra}

Untuk mengatasi problema tersebut dengan memotivasi ibu rumah tangga Gampong Sungai Pauh Pusaka selaku mitra sebagai berikut: (1) Tim pengabdian masyarakat akan memberikan pelatihan keterampilan produk olahan pelembut dan pewangi laundry pada Ibu PKK Gampong Sungai Pauh Pusaka; (2) Tim pengabdian akan memberikan ilmu pengetahuan proses pemasaran produk olahan aroma terapi lavender sebagai Anti- Nyamuk (Aedes aegypti) yang dilakukan dengan cara melalui media sosial dan konvensional; (3) Tim pengabdian akan monotoring dan mengevaluasi sejauh mana produksi produk berjalan di masyarakat.

\section{METODE PELAKSANAAN}

Pelaksanaan pengabdian yang akan dilaksanakan oleh tim pengabdian tim pengabdian kepada masyarakat melaksakan kegiatan pengabdian dengan Ibu PKK Gampong Sungai Pauh Pusaka yang dilaksanakan pada bulan Juli sampai Agustus 2021. Proses pelaksanaan kegiatan pengabdian menggunakan alat yaitu kompor gas, tabung gas, panci, gelas ukur, pengaduk, ember, tong air dan botol. Sedangkan bahan yang digunakan dalam pembuatan parfum laundry adalah bahan 
pelicin, stabilizer, pengawet, pengikat parfume dan parfume terapi lavender.

Tahap selanjutnya akan dilakukan proses kegiatan pengabdian yang terdiri dari 3 (tiga) tahapan yang meliputi; (1) survey; (2) pelatihan keterampilan pembuatan parfum laundry aroma terapi bunga lavender; (3) monotoring dan evaluasi. Metode pelatihan ini dimaksudkan untuk memberikan gambaran dan dorongan kepada Ibu PKK Gampong Sungai Pauh Pusaka sebagai usaha rumah tangga atau usaha kelompok desa (Nursamsu dan Allif, 2020).

\section{HASIL DAN PEMBAHASAN}

\section{Tahap Survey}

Tahap survey dilaksanakan sebelum pengabdian dimulai, pada tahap ini tim pengabdian berkoordinasi terlebih dahulu kepada Ibu ketua PKK Gampong Sungai Pauh Pusaka. Hal yang di bicarakan pada Ibu ketua PKK untuk melaksanakan pengabdian. Kesepakatan kerja untuk melaksanakan pelatihan pembuatan parfum laundry seperti jadwal dalam kegiatan pengabdian dan menetukan jumlah peserta yang dilatih. Bukti dari kegiatan ini dapat dilihat pada gambar di bawah ini.

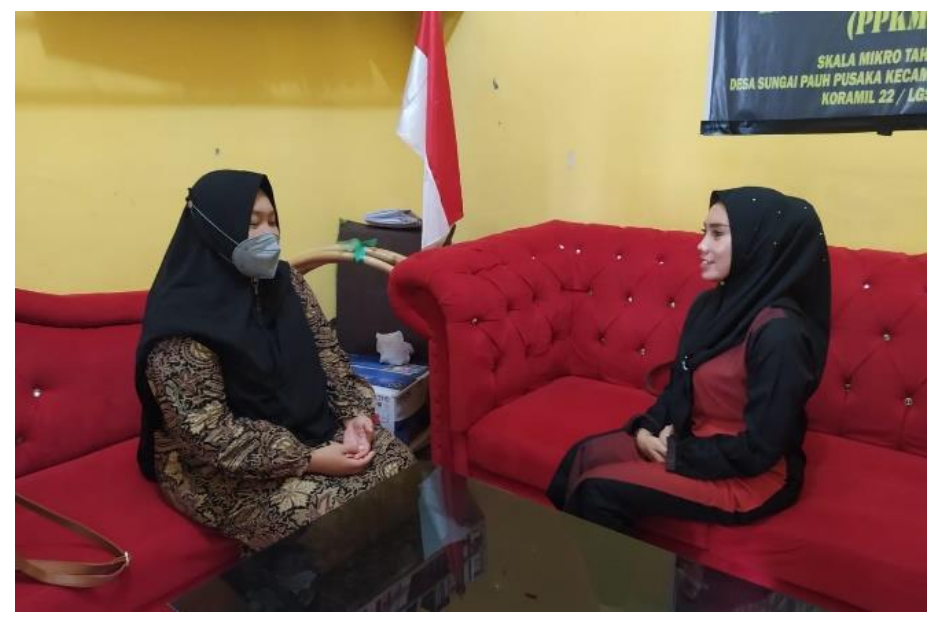

Gambar 1. Tim Survey Kepada Ibu Ketua PKK Gampong Sungai Pauh Pusaka

\section{Tahap Pelatihan}

Ada beberapa proses yang dilaksanakan oleh tim pengabdian untuk menjelaskan pembuatan parfum laundry sebagai berikut.

a. Tahap pertama persiapan tim pengabdian menyiapkan alat dan bahan dalam pembuatan parfum laundry. Pada tahap ini tim memperkenalkan alat dan bahan 
kepada peserta yang dilatih bergabung dalam organisasi PKK Gampong Sungai Pauh Pusaka seperti alat (kompor gas, tabung gas, panci, gelas ukur, pengaduk, ember, tong air dan botol). Sedangkan bahan yang digunakan dalam pembuatan parfum laundry adalah bahan pelicin, stabilizer, pengawet, pengikat parfume dan parfume terapi lavender.

b. Tahap kedua tim pengabdian membuka acara pelatihan terlebih dahulu yang dilakukan oleh ketua pengabdian kepada masyarakat. Dimana ketua memberikan penjelaskan tujuan dari kegiatan pengabdian kepada peserta yang dilatih. Hal ini dapat di buktikan pada gambar 2 dibawah ini.

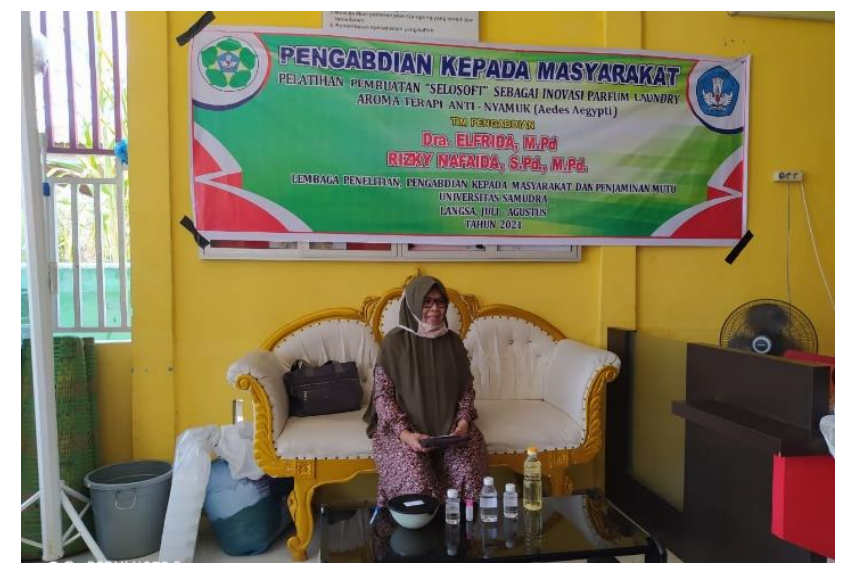

Gambar 2. Kata Pembuka Ketua Pengabdian

c. Tahap Pembuatan Parfum Laundry Aroma Terapi Bunga Lavender.

Pada tahap ini tim pengabdian memberikan penjelasan bahan apa sajakah untuk membuat parfum laundry aroma terapi bunga lavender dapat dijelaskan sebagai berikut; (1) Rebuskan 2 liter air panas; (2) Sudah air mendidih masukkan bahan pelicin dan diaduk sampai tidak gumpalan lagi; (3) Masukkan 25 liter air bersih kedalam tong air; (4) Masukkan bahan stabiliter; (5) Masukkan bahan pengawet; (6) Masukkan bahan pengikat parfume; (7) Masukkan pelicin yang sudah larut dalam air sebagai pelembut pakaian; (8) Masukkan parfume berlahan - lahan. Setelah bahan tercampur maka diaduk sampai rata. selanjutnya masukkan pelembut dan pewangi pakaian kedalam botol yang telah disediakan. Bukti proses pembuatan dapat dilihat pada gambar 3 di bawah ini. 


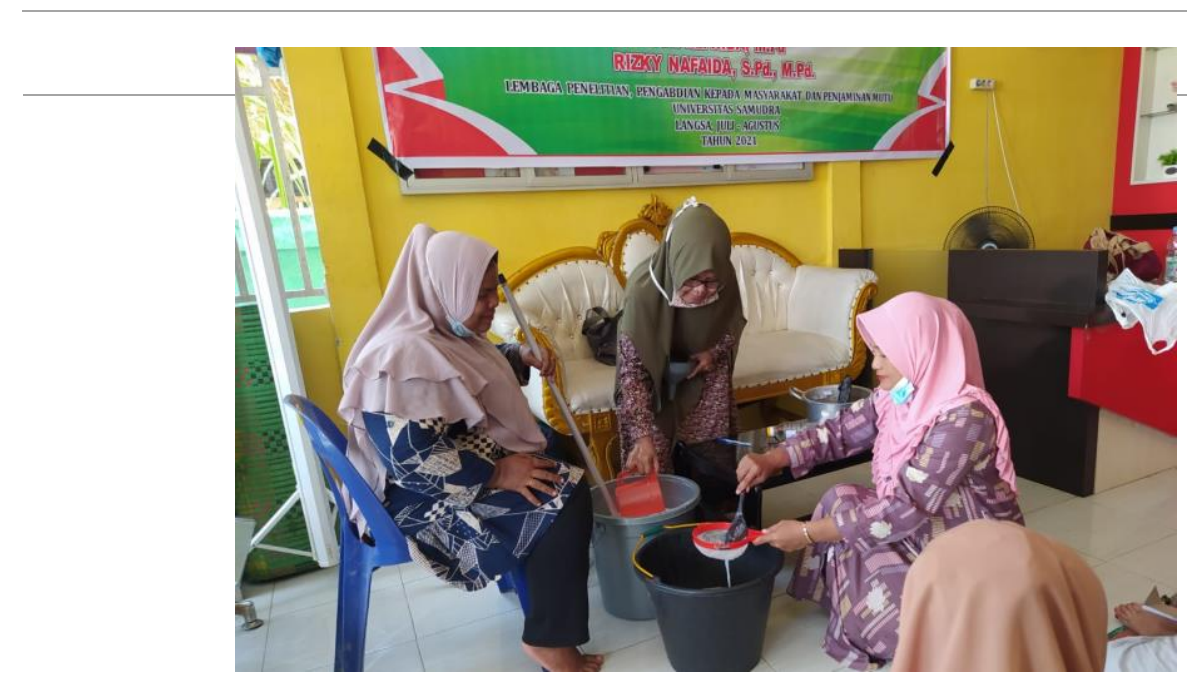

Gambar 3. Proses Pembuatan Parfum Laundry

d. Tahap proses pengemasan produk

Pada tahap pengemasan ini dilaksanakan oleh tim pengabdian dengan Ibu PKK Gampong Sungai Pauh Pusaka sebagai peserta yang dilatih. Produk yang telah di buat maka tim dan peserta melakukan pengemasan produknya yang dapat dilihat pada gambar 4 dibawah ini.

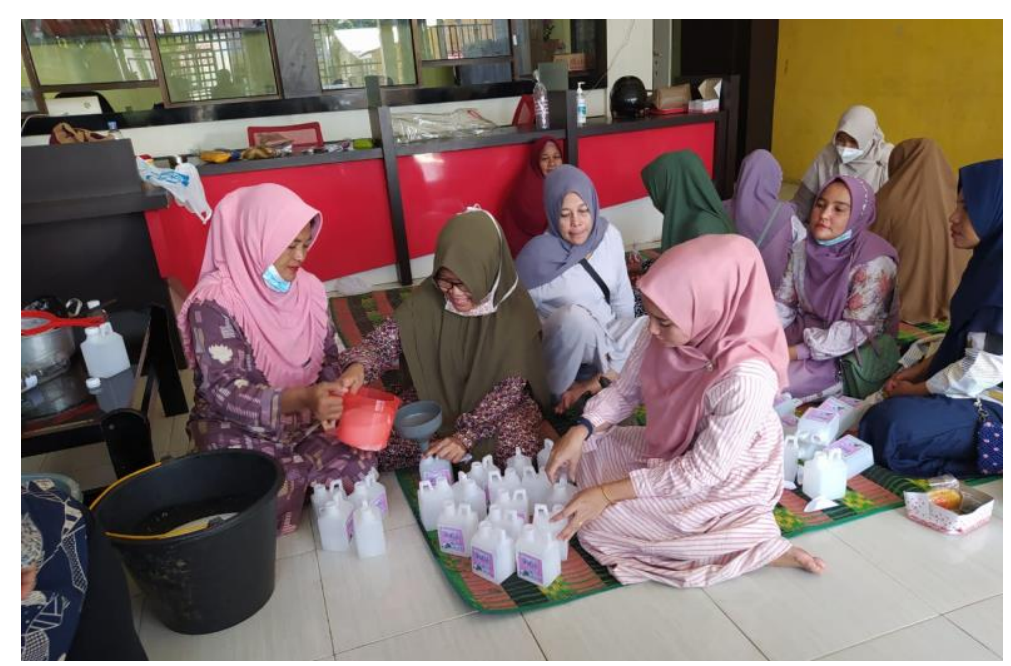

Gambar 4. Proses Pengemasan Produk

e. Produk Siap Dipasarkan

Pada tahap ini produk yang telah dibuat oleh tim pengabdian dengan Ibu PKK Gampong Sungai Pauh Pusaka, di jual sebagai pendapat usaha mikro gampong. Hal ini dapat dilihat pada gambar 5 dibawah ini. 


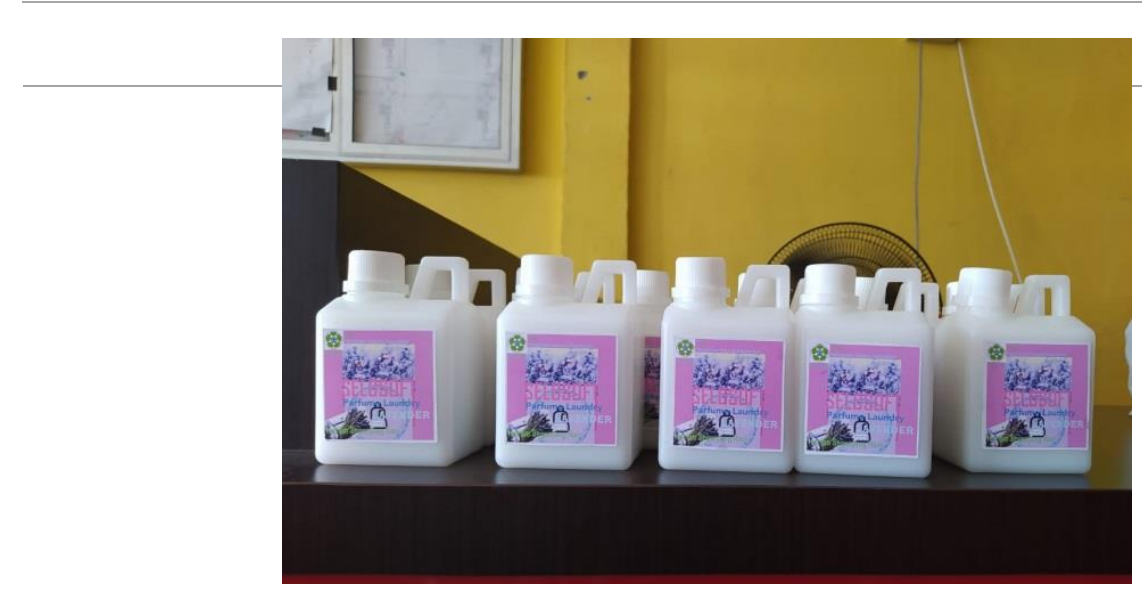

Gambar 5. Produk Parfum Laundry Aroma Terapi Bunga lavender

\section{Tahap Monotoring dan Evaluasi}

Pada tahap motoring tim pengabdian turun ke lokasi tempat mitra untuk mengetahui sejauh mana kegiatan pengabdian telah dilaksanakan. Hasil yang tim pengabdian dapatkan bahwa kegiatan ini sangat memuaskan. Mitra melakukan kegiatan untuk diproduksi produk dijadikan usaha gampong. Selanjunya dilakukan evaluasi dari kegiatan tersebut, tim pengabdian melakukan penyebaran angket kepuasanan dalam pelaksanakan kegiatan pelatihan pembuatan produk parfume laundry aroma terapi bunga lavender.

Tabel 1. Angket Kepuasaan Pelatihan Pembuatan Parfum Laundry

\begin{tabular}{|c|c|c|c|c|c|}
\hline \multirow[t]{2}{*}{ No } & \multirow[t]{2}{*}{ Uraian Pernyataan } & \multicolumn{4}{|c|}{ Skor Angket } \\
\hline & & $\mathbf{Y a}$ & $\%$ & Tidak & $\%$ \\
\hline 1. & $\begin{array}{ll}\text { Bagaiamana } & \text { menurut pendapat Ibu } \\
\text { Program } & \text { Pengabdian } \\
\text { Masyarakat(PKM } & \end{array}$ & 16 & 80 & 4 & 20 \\
\hline 2. & $\begin{array}{l}\text { Materi proses pembuatan parfum laundry } \\
\text { pakaian pelaksanaan program PKM } \\
\text { memberikanpengetahuan }\end{array}$ & 15 & 75 & 5 & 25 \\
\hline 3. & $\begin{array}{l}\text { Pelaksanaan program memberikan } \\
\text { keterampilan bagi Ibu }- \text { Ibu dalam } \\
\text { peluang usaha }\end{array}$ & 14 & 70 & 6 & 30 \\
\hline 4. & $\begin{array}{l}\text { Personil/anggota yang terlibat dalam } \\
\text { kegiatan } \\
\text { pengabdian masyarakat memberikan } \\
\text { pelayanan sesuai dengan kebutuhan } \\
\text { saya }\end{array}$ & 18 & 90 & 2 & 10 \\
\hline 5. & $\begin{array}{l}\text { Setelah pelaksanaan program PKM } \\
\text { akan dilanjutkan lagi untuk membuat } \\
\text { produk }\end{array}$ & 17 & 85 & 3 & 15 \\
\hline & Jumlah Rata-Rata & 80 & 80,0 & 20 & 20,0 \\
\hline
\end{tabular}




\section{KESIMPULAN}

Proses kegiatan pengabdian kepada masyarakat berjalan dengan lancar dari tahap-tahapan yang telah dilaksanakan. Ibu PKK Gampong Sungai Pauh Pusaka kegiatan pengabdian memberikan dampak positif, kegiatan ini akan berkelanjutan.

\section{UCAPAN TERIMA KASIH}

Terima kasih Tim Pengabdian Kepada Masyarakat kepada LPPM \& PM Universitas Samudra yang telah memberikan kontribusi dana, sehingga kegiatan ini berjalan dengan pada waktunya.

\section{DAFTAR PUSTAKA}

Afrianti, W.W. \& Suhardi. (2015). Penurunan Kecemasan Menghadapi Skripsi Dengan Menggunakan Aromaterapi Inhalasi. Jurnal Terpadu Ilmu Kesehatan, 4(2): 82-196.

Conrad P, Adams C. (2012). The effect of clinical aromatherapy for anxiety and depressionin the high risk postpartum woman. Complement Ther Clin Pract. 18(3):164-8.

Handoko, H.B. (2009). Laundry Chemicals. Medan : Universitas Sumatera Utara.

Laksono Endang. W, SYL Isana, Marfuatun, L. Dewi Yuanita, (2018). Pelatihan Pembuatan Pelembut Cucian yang Ramah Lingkungan, J. Pengabdian Masyarakat MIPA dan Pendidikan MIPA, 2(1): 38-42. http://journal.uny.ac.id/index.php/jpmmp.

Nursamsu \& Allif Syahputra Bania. (2020). Pelatihan Pembuatan Pelembut Dan Pewangi Pakaian Bagi Ibu-Ibu PKK Bina Mufakat Di Desa Bayeun Kecamatan Birem Bayeun Kabupaten Aceh Timur. J-ABDIPAMAS (Jurnal Pengabdian Kepada Masyarakat), 4(2): 21-27. http://ejurnal.ikippgribojonegoro.ac.id/index.php/J-ABDIPAMAS.

Ohayon MM, Reynolds CF, Ali B, Al-Wabel NA, Ahmad A, Shams S. (2015). Essential oils used in aromatherapy: a systemic review. Asian Pac J Trop Biomed. 5(8):601-11.

Scheibel, J. J. (2004). The Evolution of Anionic Surfactants Technology to Meet the Requirements of the Laundry Deterjent Industry, J. Surfactants. Deterg.7(4): 319-328. 